\title{
Erratum zu: Mit Mut zu schnellen Entscheidungen aus dem Bauch heraus
}

\section{Erratum zu: \\ Kapitel 17 in: Hildebrandt und W. Neumüller (Hrsg.), Bauchgefühl im Management, https://doi.org/10.1007/978-3-662-63667-1_17}

Trotz sorgfältiger Erstellung unserer Bücher lassen sich Fehler nicht vermeiden, daher weisen wir auf Folgendes hin:

Es wurden inhaltliche Korrekturen zu diesem Kapitel vorgenommen 